\title{
Oral Health in Children with Intellectual Disabilities in Banja Luka Municipality
}

\begin{abstract}
Introduction: Dental care for people with mental disabilities is an integral part of the comprehensive medical care. Mentally challenged people, in addition to mental have, in cases of severe psychophysical development disorders, motor disturbances as well, which prevent them from adequately maintaining oral hygiene and general health. In institutions where these people are located, there is often no dental service or dentist to take care of their oral health.
\end{abstract}

Aims of the study: The basic goal of the reasearch is to determine the oral health condition of the intelectually disabled children in the municipality of Banja Luka.

Patients and Methods: The study was conducted on 65 children (26 females and 39 males), age range: 5 to 15 years old. According to a type of disability by 10 th International classificiation of the diseases, children were divided into two groups: group 1/F71(n=35) and group 2/F72 ( $=30)$. Dental check assessed: teeth number, presence of decayed, missing/extracted teeth and radices relictae, presence and number of crowns, gingival index-Gl and plaque index-PI.

Results: The analysis showed there was no significant difference in the number of decayed, extracted, filled teeth and there were no significant differences in the values of DMFT, gingival and plaque index.

Conclusion: Children with mental disabilities in the municipality of Banja Luka have a bad state of the mouth and teeth. In relation to the degree of mental disability of children, there was no significant difference in the number of decayed, extracted, filled teeth, DMFT, gingival and plaque index .

\section{Key words:}

children with mental disabilities, tooth decay, DMFT

DOI: $10.7251 / S M D E N 1501012 I$

(Scr Med 2015:46:12-17)

\section{Sanja Ilić ${ }^{1}$, Ranka Knežević ${ }^{1}$}

${ }^{1}$ PHI Institute of Dentistry Banja Luka, Zdrave Korde 4, $780 o o$ Banja Luka, the Republic of Srpska

\section{Contact address:}

Sanja Ilić, PHI Institute of

Dentistry Banja Luka

Zdrave Korde 4,

$780 o$ o Banja Luka,

Bosnia and Herzegovina,

Tel. oo387 65 689-969,

e-mail: i.sanja73@gmail.com
Submitted: January 9th, 2015 Accepted: February 2th, 2015

\section{Introduction}

Oral health, as an integral part of general health and wellbeing of a human, ${ }^{1}$ has a great influence on everyday functioning and life quality of intellectually disabled people which are in general additionally worsened by diseases of other systems and organs. ${ }^{2}$ There is a continuous increase in number of intellectually disabled people, which is contrary to the development degree of health protection. 
Nevertheless, the development of medical science today significantly influences the prolongation of lifespan of such people, although the insufficient attention is paid to their oral health. Reasons for bad oral health of such people are numerous and complex. Namely, intellectually disabled people are most often accommodated in special institutions and rarely in households. In such special institutions there is often no dental service, i.e. dentist to take care of their oral health. ${ }^{1}$ With such people who live with their perents or legal guardians, the oral care is taken by their parents, i.e. guardians who usually do not cooperate properly with the dentist and are not correctly informed about the importance of oral health preservation.

Oral hygiene of intellectually disabled people is worse than the one of healthy people and they suffer from more developed paradontium diseases than healthy people. Being occupied by primary mental disease and ignorant of the importance of dental health, parents or guardians are usually insignificantly motivated to preserve the oral health of intellectually disabled children. Such people have aggravated cooperation with dentists and there are also not many dentists who work with intellectually disabled children. Low level of oral hygiene, great caries and paradontal diseases prevalence are characteristic of intellectually disabled people. Such people almost always maintain the oral hygiene insufficently, as they are not capable of learning nor understanding the importance of oral hygiene practice. ${ }^{3}$ Special courses and other educational tools are necessary for the nursers in order to enable them to understand the importance of oral health and to manage the correct techniques of oral hygine practice. 4,5

Health and educational work referring to oral health of intellectually disabled people should be an integral part of their primary disease treatment, i.e. should be within the already prescribed terapy in order to improve the overall quality of their life. ${ }^{6,7}$

Damaged oral health is additionaly aggravating the nutrition and communication with such patients. ${ }^{8}$ Furthermore, such patients often take numeruos medicines which can also influence the oral helath (reduce salivation, cause gum infection, lead to bone resorption and to parodonthopy). Taking of analgetics can also hide certain disease symptoms in these patients. ${ }^{9}$

Hypersalvation leads to reduction in salivary activity of cleaning thus having a dental plaque accumulate in marginal gingival area. The consequences of hypersalvation are inadequately puffered acids produced by increasing number of bacteria, which, in the end, cause teeth decay. ${ }^{10}$

Most of these people are often either teethless or with few teeth, suffering from extensive acute caries, high KEP index and developed periodontium diseases. ${ }^{11}$
Dental care of intellectually disabled people represents the biggest problem, as well as challange for the dentist. It is very important for the dentist to win their sympathy, i.e. to establish friendly relationship. Intellectually disabled people are hyperactive and upset while being at the dentist, they have unpredicted emotional reaction and attention shortage. ${ }^{12}$

Noninvasive dental interventions, such as machine-used removal of soft layers, tartar or local fluoride application can be made in high percentage of intellectually disabled children at the dental clinic. ${ }^{13}$

Regarding intellectually disabled children of younger age who do not accept cooperation, a short dental intervention can be made with the help of parent or guardian having a child in their lap with their legs over the legs of the child and fixing the arms and body of the child with their hands. In this way, a dental check-up can be made together with some preventive measures, drainage or tooth extraction. With intellectually disabled children of older age, the presence of parents/guardians is requested, i.e. the presence of the person who brought the patient, so that he/she could prevent the possible violent behaviour of the patient. ${ }^{14}$

In cases when it is impossible to provide conventional dental treatment, sadation or general . anesthesia is used. There are few publications on oral health of intellectually disabled people in the world and especially in our country.

\section{Aims of the study}

The basic goal of the reasearch is to determine the oral health condition of the intelectually disabled children in Banja Luka municipality.

\section{Patients and Methods}

This research involved 65 intellectually disabled respondents, out of which 26 were females(40\%) and 39 male (60\%), at the age of 5 - 15 years, i.e. average age 10 years. The research comprised children living with parents/ guardians and children accommodated with the following institutions: PI Centre "Zaštiti me" and Institution of physical medicine and rehabilitation "Dr Miroslav Zotovic" Banjaluka. The respondents were divided into two groups according to the level of the intellectual disability as defined by the 1oth audit of the International disease classification (MKB-10). There were 35 respondents with F71-diagnosis - moderate intelectual disability and 30 respondents with the diagnosis F72- severe intellectual disability. Their teeth condition was examined and determined at the Maxiofacial Surgery Clinic of the Clinical Centar Banja Luka and the teeth treatment was conducted in the period between January 1st, 2012 and December 31st, 2012.

A dental mirror, a probe and artificial light were used in the dental examination, as recommended by the World Health 
Organisation. Upon the dental examination, the dental record was filled in

(number of teeth, caries presence, existing fillings, number of extracted teeth, remained teeth radices relica, possible presence of dental prostheses).

KEP index was used in the estimation of teeth condition. All parents/guardians were familiar with the purpose of the reasearch and confirmed by their signatures thier participation in the research.

Löe and Silnes gingival index was used for the estimation of the gingiva condition and the dental plaque presence was also established using the Silnes oe.

All the data were processed using standard procedures of descriptive and comparative statistics. Within the descriptive statitics, the average value was determined as well as standard deviation, and within the comparative statitics: Kruskal-Wallis test, Student test and $\chi^{2}-$ test.

\section{Results}

The analysis showed that there was no significant difference in the number of caries affected, extracted or filled teeth, in comparison to the level of intellectual disability of the children. The average value of the caries affected teeth in children with mild intellectual disability amounted to 8.5 , whereas, in the case of shildren with more severe intellectual disability, it amounted to 8.7. The average value of the extracted teeth in children with mild intellectual disability amounted to 0.3 , whereas in children with severe intellectual disability, it amounted to 0.4. The average value of the filled teeth in children with mild intellectual disability amounted to 0.25 , whereas in children with severe intellectaual disability, it amounted to 0.17.

On the basis of the conducted Student test there was no statistically significant difference in the number of caries affected, extracted and filled teeth in relation to the level of intellectual disability in children (Table 1.).

Table 1. Results DMFT index in relation to the degree of mental disability of children

\begin{tabular}{llccc}
\hline & $\begin{array}{l}\text { Degree of mental } \\
\text { disability }\end{array}$ & $\mathrm{N}$ & $\bar{x}$ & SD \\
\hline \multirow{2}{*}{ Decayed } & deminished & 36 & 8.472 & 4.266 \\
\cline { 2 - 5 } & weighs & 29 & 8.759 & 5.138 \\
\hline \multirow{2}{*}{ Extracted } & deminished & 36 & .306 & .856 \\
\cline { 2 - 5 } & weighs & 29 & .448 & 1.021 \\
\hline \multirow{2}{*}{ Filled } & deminished & 36 & .250 & .770 \\
\cline { 2 - 5 } & weighs & 29 & .172 & .658 \\
\hline \multirow{2}{*}{ DMFT } & deminished & 36 & 9.028 & 4.253 \\
\cline { 2 - 5 } & Weighs & 29 & 9.379 & 5.596 \\
& deminished & 36 & 9.028 & 4.235 \\
\hline
\end{tabular}

There was no significant difference in KEP values in children with different level of intellectual disability. Regarding the children with mild intellectual disability, the average value of KEP amounted to 9 whereas in those having severe intellectual disability, it amounted to 9.4 .

There was no statistically significant difference in KEP values in relation to the level of intellectual disability as shown by conducted Student test (Table 1.).

The results showed that the respondants with severe intellectual disability had higher average value of Caries tooth index (KIz-a) (40) than those with mild intellectual disability who had their average value KIz-a (35). This difference was not statistically significant $(\mathrm{t}=1.009 ; \mathrm{p}<$ o.317) (Table 2.).

Table 2. Value PCC in children respondents in relation to the degree of disability

\begin{tabular}{lllllllll}
\hline & \multicolumn{6}{c}{ Klz } \\
\cline { 2 - 8 } & $\mathrm{N}$ & $\bar{x}$ & SD & Med & Min & Maks \\
\hline Degree & weighs & 29 & 40.55 & 23.92 & 32.00 & 11.54 & 96.43 \\
\cline { 2 - 8 } $\begin{array}{l}\text { of mental } \\
\text { disability }\end{array}$ & teminished & 36 & 35.42 & 17.04 & 35.10 & 12.50 & 87.50 \\
\hline
\end{tabular}

The average value of gingival index in children with mild intellectual disability amounted to $1.2 \pm 0.6$ whereas in children with severe intellectual disability, it amounted to $1.4 \pm 0.6$. The average value of plaque index in children with mild intellectual disability amounted to $1.8 \pm 0.5$ whereas in children with severe intellectual disability, it amounted to $1.9 \pm 0.7$.

Figure 1. Gingival index of children in relation to the degree of mental disabilities

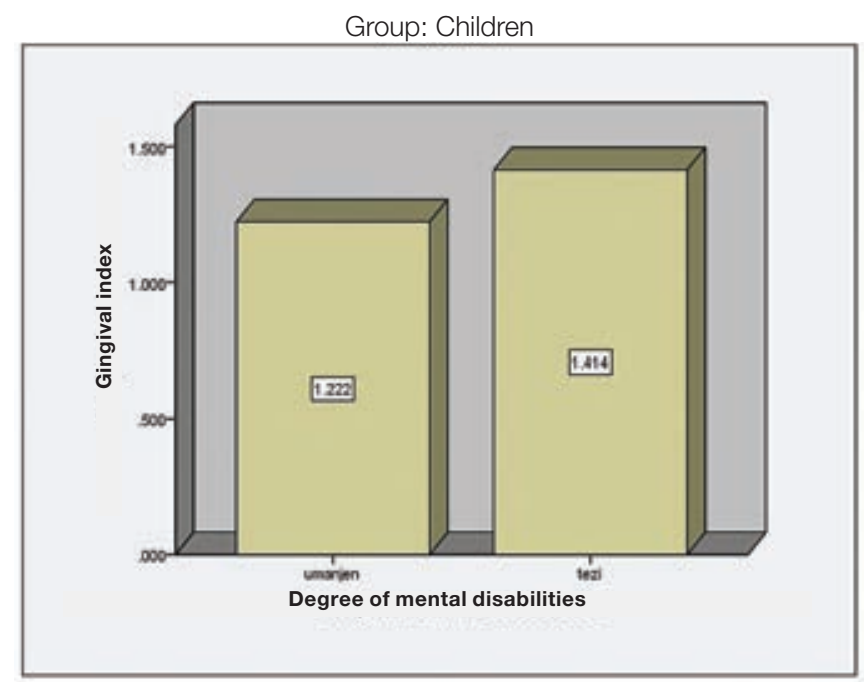


Figure 2. The plaque index of children in relation to the degree of mental disability

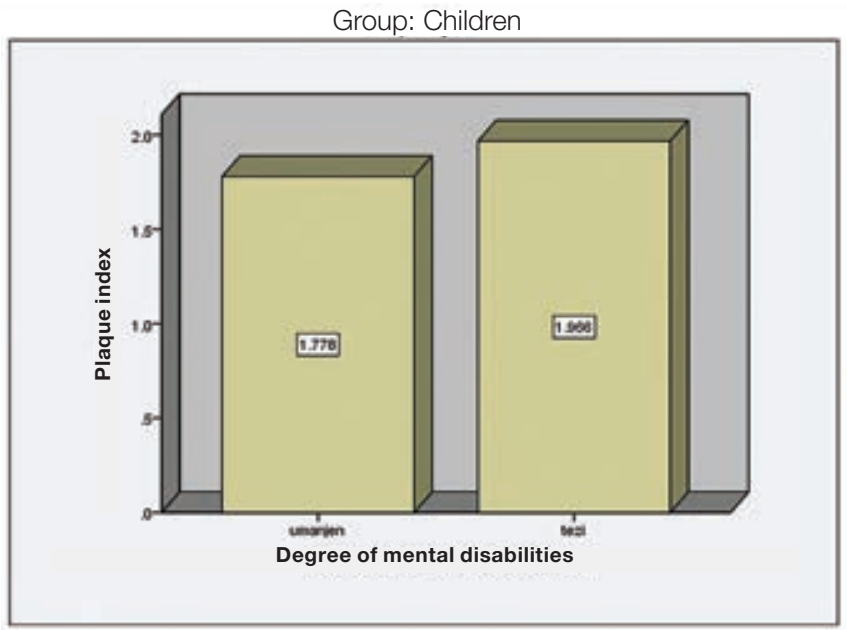

According to the Student's t -test there was no statistically significant difference in the values of gingival and plaque index in the children groups in relation to the level of their intellectual disability.

\section{Discussion}

The results of this research showes that children with severe intellectual disability had more caries affected and extracted teeth as well as higher average KEP values, but there was no statistically significant difference in the number of extracted, filled and caries affected teeth in relation to their level of intellectual disability.

The study conducted in Turkey by Altun and his coworkers showed that the level of oral hygiene practice significantly worsened with the age and that KEP was increasing. Namely, having examined 160 schoolage children with intellectual disabiilty, they found out that the average KEP value in children up to six (6) years was 2,04, in chidren up to 12 years 2,24, and with those up to 26 years even 11,9 , which was in accordance with our results and was explained by inadequate oral hygiene and longer presence of teeth plaque..$^{15}$

Long stay at home combined with consumption of nibbles and sweetened drinks influenced increased caries occurance. ${ }^{16}$ Butts “ findings show that only $17 \%$ of intellectually disabled children who lived at home had no caries, whereas $38 \%$ of those accommodated with institutions had healthy teeth. The reasons for this were consumptions of nibbles and sweetened drinks while at home, as well as irregular teeth brushing. ${ }^{17}$ Research conducted by Cutreess confirmed our results. ${ }^{18}$

In her research, Jovicic found out that there was no statistically significant difference between the condition of milk teeth of health and intellectually disabled children at the age 3-6 years, i.e. between different groups of intellectually disabled children. The condition of periodontium was much worse in children affected by celebral paralysis and those intellectually disabled than in healthy children. ${ }^{19}$

The research conducted in Croatia focused on the estimation of health condition of mouth cavity and teeth with intellectually disabled children and those helathy ones. The average KEP index value with intellectually disabled children amounted to 1,41 for mixed dentition and 6,39 for permanent dentition. Regarding healthy children, these values amounted to 1,23 for mixed dentition and 4,76 for permanent dentition. The results did not show statistically significant difference in caries intensity in different researched groups. Intellectually disabled children showed significantly worse oral hygine practice than healthy children. ${ }^{20}$

In their research conducted in Srbija, Gajić and Stevanović concluded that that there was statistically significant percentage of untreated milk teeth caries in intellectually disabled children in relation to the controlled group of helathy children. Intellectually disabled children also showed increased prevalence of paradontal diseases, especially those accommodated with social institutions. There was also a big difference in KEP structure with intellectually disabled people, i.e. much lower percentage of filled teeth and much more caries affected teeth. ${ }^{21}$

The research conducted by Kocic and his coworkers was contrary to the aforementioned. According to Kocic, the greatest milk teeth caries prevalence was noticed in children with mild intellectual disability, then in physically disabled children and the lowest caries prevalence was noticed in children with severe intellectual disability whose milk teeth were in the best health. It was further found out that there was no difference in the average number of damaged permanent teeth upon examined child at the age of 7-8 years, among physically disabled children $(\mathrm{KIp}=5,1)$, children with mild intellectual disability $(\mathrm{KIp}=5,6)$ and group of healthy children $(\mathrm{KIp}=5,7) .{ }^{22}$

The obtained results showed that that children with severe intellectual disability had more plaque and higher gingival index in relation to children with mild intellectual disability. However, this difference was not statistically significant.

Most authors agree with the conclusion that the oral hygiene condition of intellectually disabled people is geeting worse with age. Inadequate oral hygine leads to dental plaque occurance. The longer it exists, it causes more serious diseases of hard, as well as soft tissues. ${ }^{23-26}$

Lack of oral hygiene can be caused by ignorance of nurses and other personnel working in institutions which accommodate intellectually disabled people. ${ }^{27,28}$ However, there is no reason to suspect that these people are 
neglected by personnel. The fact is that the personnel do not have sufficient knowledge and education on how to treat intellectually disabled people and how to offer them the most adequate dental service in sense of adequate and correct oral hygine. ${ }^{29,30}$

The education was provided during the first control which was scheduled seven days after an intervention carried out in general anesthesia. Within this reasearch the education by means of lectures and brochures on correct oral hygine and its importance was provided to people taking care of intellectually disabled ones. It was noticed that it came to much better cooperation, especially in people with mild intellectual disability. This small, but important step in communication is ascribed to positive experience during mouth and teeth treatment in general anesthesia.

The available literature on this topic suggests that efficient instructions for oral cavity hygiene maintenance should actively include psychiatric patients. Furthermore, it points out the necessity for specific preventive dental programmes with the aim to improve behaviour of this population regarding oral health protection. Klark ${ }^{31}$ however states that each preventive programme for improvement of oral health designed for healthy population requires significant changes in order to be adapted to the needs of this specific group of patients.

Researches point out that there are many intellectually disabled children who are not capable of oral hygine maintenance, and parents or guardians are usually unmotivated and uneducated. It is therefore very important to include parents/guardians as well as teachers in oral hygiene practice programmes designed for intellectually disabled people, so that they could successfully implement the prevention programme together with dentists. Health and educational work is a longterm and painstaking process with the aim not only to teach these people, but to prepare them to use this knowledge. ${ }^{32}$

\section{Conclusion}

Intellectually disabled children from Banja Luka municipality have bad mouth and teeth condition, but in realation to the level of intellectual disability, there was no significant difference in the number of caries affected, extracted and filled teeth, as well as in KEP, Kiz, gingival and plaque index.

Health and educational work in necessary as an integral part of terapy within the treatment of intellectually disabled people, and it should also include parents/ guardians.

Various education modes, trainings on oral hygine practice, prevention measures and improvement of general health consciousness in all segments of the society could contribute to higher quality life of intellectually disabled people.

\section{References}

1. Savić-Stanković T, Jovanović-Medojević M, Živković S, Dental status of institutionalized people with special needs who live in special institution „Srce u jabuci“ in Pancevo, Serbian Dental Journal. 2011; 58(1):16-22.

2. Caplan AL; McCartney JJ, Sisti DA. Health, Disease, and Illness: Concepts in Medicine. Washington, D.C.: Georgetoven Universety Press. 2004; 33:8-22.

3. Gajić M, Stevanović R: Hendikepirano dete u stomatološkoj ordinaciji. 2002; 8:20-1.

4. Frenkel HF, Harvey I, Newcombe RG, Improving oral health in institutionalized elderly people by educating caregivers: a randomised controlled tried. Community Dent Oral Epidemiol. 2001; 29:289-97.

5. O'Keefe E, Oral health of patients with intellectual disabilities. Evid Based Dent. 2010;11(3):81.

6. Jovanović S, Gajić I, Mandić J, Mandić B. Navike, stavovi i ponašanje osoba s psihijatrijskim oboljenjima u odnosu na zdravlje usta i zuba. Srpski arhiv za celokupno lekarstvo. 2010; 138(34):136-142.

7. Jovanović S, Gajić I, Mandić B, Mandić J, Radivojević V. Oralne promene kod osoba s psihijatrijskim oboljenjima. Srpski arhiv za celokupno lekarstvo. 2010; 138(9-10):564-569.

8. Gomes VN, Frigerio ML, Fidelix M. Bone mass index analysis in elderly people before and after change prosthesis. Gerodontology. 2006 Sep;23(3):187-91.

9. Budtz-Jorgensen E. Prosthodontics for Elderly: Diagnosis and Treament. Chicago, IL: Quintessence. 1999; 25:154-62.

10. Jovanović S, Gajić I. Oralno zdravlje osoba sa psihotičnim poremećajem. Serbian Dental J. 2008; 55.

11. Eihara T, Yamaya M, Ohrui T, Arai H, Sasaki H. Comparasion of disabled older people in the USA and Japan. Geriatr gerontol Int. 2002; 2:53-6.

12. Vermeulen M, Vinckier F, Vandenbroucke J. Dental general anesthesia: clinical charcteristics of 933 patients. J Dent Child. 1991; 58:27-30.

13. Stevanović R. Gajić M. Somatološko zbrinjavanje dece ometene u psihofizičkom razvoju. Dečja stomatologija. Elit-Medica. 2000; 8:27-33.

14. Stevanović R. Gajić M. Somatološko zbrinjavanje hendikepirane dece u opštoj anesteziji. XIX Stom. nedelja Srbije. 1991.

15. Altun C, Guven G, Akgun OM, Akkurt MD, Basak F, Akbulut E. Oral health status of disabled individuals attending special schools. Eur J Dent. 2010 Oct;4(4):361-6.

16. Balogh RS, Ouellette-Kuntz H, Hunter DJ. Regional variation in dental procedures among people with an intellectual disability, Ontario. 1995-2001. J Can Dent Assoc. 2004; 70:681a-681f.

17. Butts JE. Dental status of mentally retarded children. A survey of the prevalence of certain dental condition in mentally retarded children in Georgia. J Public Health Dent. 1967; 27:195.

18. Curtess T. Dental caries in Trisomy 21. Arch Oral Biol. 1971; 16:1329.

19. Jovičić O. Karakteristike oralne patologije kod dece ometene u psihofizičkom razvoju. Magistarski rad, Beogradski univerzitet, Beograd. 2001. 
20. Ivancić Jokić N, Majstorović M, Bakarcić D, Katalinić A, Szirovicza L. Dental caries in disabled children. Collegium Antropologicum 2007; 31 (1): 321-4.

21. Gajić M, Stevanović R: Hendikepirana deca u stomatološkoj ambulanti. Zbornik rezimea sa VIII kongresa preventivne medicine Jugoslavije sa međunarodnim učešćem, Beograd. 1995; 8:38-9.

22. Kočoć D. Epidemiologija i mogućnosti terapije karijesa kod dece ometene u psiho-fizičkom razvoju. Magistarski rad, Univerzitet u Nišu, Niš. 1996.

23. Kumar M, Chandu GN, Shafiulla MD. Oral health status and treatment needs in institutionalized psychiatric patients: one year descriptive cross sectional study. Indian J Dent Res. 2006; 17:171-7.

24. Angelillo IF, Nobile CG, Pavia M, De Fazio P, Puca M, Amati A. Dental health and treatment needs in institutionalited psychiatric patients in Italy. Community Dent Oral Epidemiol. 1995; 23:3604.

25. Lewis S, Jagger RG, Treasure E. The oral health of psychiatric in patients in South Wales. Spec Care Dentist. 2001; 21(5):182-6.

26. Kenkre AM, Spadigam AE. Oral health and treatment needs in institutionalized psychiatric patients in India. Indian J Dent Res. 2000; 11(1):5-11.
27. Jovanović S. Prevencija oralnih oboljenja hospitalizovanih osoba sa psihotipnim poremećajima [doktorska teza]. Univerzitet u Beogradu, Stomatološki fakultet, 2008.

28. Stanfield M, Scully C, Davison MF, Porter S. Oral healthcare of clients with learning disability: changes following relocation from hospital to community. Br Dent J. 2003; 194:271-7.

29. Kisely S, Quek LH, Pais J, Lalloo R, Johnson NW, Lawrence D. Advanced dental disease in people with severe mental illness: systematic review and meta-analysis. The British Journal of Psychiatry. 2011; 199:73-9.

30. Teng PR, Su JM, Chang WH, Lai TJ. Oral health of psychiatric inpatients: a survey of central Taiwan hospitals. General Hospital Psychiatry 2011; 33:253-9.

31. Boyd D, Quick A and Murray C. The Down syndrome patient in dental practice, Part II: clinical considerations. New Zealand Dental Journal. 2004;100:4-9.

32. Jovanović S, Milovanović SD, Gajić I, Mandić J, Latas M, Janković LJ. Oral health status of psychiatric in patients in Serbia and implicationes for their dental care. Croat Med J. 2010;51:443-50.

\section{Oralno zdravlje djece ometene u mentalnom razvoju na području opštine Banja Luka}

\section{SAŽETAK}

Uvod: Stomatološko zbrinjavanje mentalno ometenih osoba je sastavni dio sveobuhvatnog medicinskog zbrinjavanja. Mentalno ometene osobe, pored mentalnih imaju, u slučajevima težeg poremećaja psihofizičkog razvoja, i poremećaje motorike, koji im onemogućavaju adekvatno održavanje oralne higijene i zdravlja uopšte.U ustanovama gdje su ove osobe smještene, često ne postoji stomatološka služba, odnosno stomatolog koji bi brinuo o njihovom oralnom zdravlju.

Cilj rada: Osnovni cilj istraživanja je da se utvrdi stanje oralnog zdravlja djece ometene u mentalnom razvoju na području opštine Banja Luka.

Ispitanici i metode: Ispitvanjem je obuhvaćeno 65 ispitanika (26 ženskog i 39 muškog pola), starosti od 5 do 15 godina. Ispitanici su svrstani u dvije grupe prema stepenu mentalnog oštećenja: MKB-10: grupa 1/F71(n=35) i grupa 2/ F72 (n=30). Stomatološkim pregledom su utvrđeni: broj zuba, prisutnost karijesa, prisutnost ispuna, broj izvađenih zuba, prisutnost zaostalih korjenova, fraktura, kao i prisutnost i broj fiksnih nadoknada, te gingivalni i plak indeks.

Rezultati: Analizom dobijenih podataka uočeno je da nema statističke razlike u broju karioznih, izvađenih i plombiranih zuba između grupa, kao ni u vrijednostima KEP-a, gingivalnog i plak indeksa.

Zaključak: Djeca ometena u mentalnom razvoju na području opštine Banjaluka imaju loše stanje usta i zuba. U odnosu na stepen mentalne ometenosti djece nije bilo značajne razlike u broju karioznih,ekstrahovanih, plombiranih zuba, kao ni u KEP, gingivalnom i plak indeksu.

\section{Ključne riječi: djeca ometena u mentalnom razvoju, karijes, KEP}

